\title{
Connexin30-Deficiency Causes Mild Hearing Loss With the Reduction of Endocochlear Potential and ATP Release
}

\author{
Junmin Chen 1,2,3t, Penghui Chen 1,2,3t, Baihui He ${ }^{1,2,3 \dagger}$, Tianyu Gong 1,2,3, Yue Li ${ }^{1,2,3}$, \\ Jifang Zhang ${ }^{1,2,3}$, Jingrong $\operatorname{Lv}^{1,2,3}$, Fabio Mammano ${ }^{4,5}$, Shule Hou ${ }^{1,2,3 *}$ and Jun Yang ${ }^{1,2,3 *}$ \\ ${ }^{1}$ Department of Otorhinolaryngology - Head \& Neck Surgery, Xinhua Hospital, Shanghai Jiaotong University School of \\ Medicine, Shanghai, China, ${ }^{2}$ Ear Institute, Shanghai Jiaotong University School of Medicine, Shanghai, China, ${ }^{3}$ Shanghai Key \\ Laboratory of Translational Medicine on Ear and Nose Diseases, Shanghai, China, ${ }^{4}$ Department of Physics and Astronomy \\ "G. Galilei", University of Padua, Padua, Italy, ${ }^{5}$ Department of Biomedical Sciences, Institute of Cell Biology and Neurobiology, \\ Italian National Research Council, Monterotondo, Italy
}

OPEN ACCESS

Edited by: Zuhong He,

Wuhan University, China

Reviewed by:

Renjie Chai,

Southeast University, China

Cheng Cheng,

Nanjing Drum Tower Hospital, China

*Correspondence:

Shule Hou

houshule8562@xinhuamed.com.cn

Jun Yang

yangjun@xinhuamed.com.cn

${ }^{\dagger}$ These authors have contributed equally to this work

Specialty section:

This article was submitted to Cellular Neuropathology,

a section of the journal

Frontiers in Cellular Neuroscience

Received: 21 November 2021 Accepted: 22 December 2021

Published: 17 January 2022

Citation:

Chen J, Chen P, He B, Gong T, Li Y,

Zhang J, LV J, Mammano F, Hou S

and Yang $J$

(2022) Connexin30-Deficiency Causes Mild Hearing Loss With the Reduction of Endocochlear Potential and ATP Release.

Front. Cell. Neurosci. 15:819194. doi: 10.3389/fncel.2021.819194
GJB2 and GJB6 are adjacent genes encoding connexin 26 (Cx26) and connexin 30 (Cx30), respectively, with overlapping expressions in the inner ear. Both genes are associated with the commonest monogenic hearing disorder, recessive isolated deafness DFNB1. Cx26 plays an important role in auditory development, while the role of $\mathrm{C} \times 30$ in hearing remains controversial. Previous studies found that $\mathrm{C} \times 30$ knockout mice had severe hearing loss along with a 90\% reduction in Cx26, while another Cx30 knockout mouse model showed normal hearing with nearly half of Cx26 preserved. In this study, we used CRISPR/Cas9 technology to establish a new Cx30 knockout mouse model $\left(\mathrm{C} \times 30^{-/-}\right)$, which preserves approximately $70 \%$ of Cx26. We found that the 1,3 , and 6 -month-old $\mathrm{C} \times 30^{-/}$mice showed mild hearing loss at full frequency. Immunofluorescence and HE staining suggested no significant differences in microstructure of the cochlea between $\mathrm{C} \times 30^{-/-}$mice and wild-type mice. However, transmission electron microscopy showed slight cavity-like damage in the stria vascularis of $\mathrm{C} \times 30^{-/-}$mice. And $\mathrm{C} \times 30$ deficiency reduced the production of endocochlear potential (EP) and the release of ATP, which may have induced hearing loss. Taken together, this study showed that lack of Cx30 can lead to hearing loss with an approximately 30\% reduction of Cx26 in the present Cx30 knockout model. Hence, Cx30 may play an important rather than redundant role in hearing development.

Keywords: connexin30, hearing loss, connexin26, stria vascularis, endocochlear potential

\section{INTRODUCTION}

Hearing loss is a major global health problem, which can be caused by continued excessive noise (Guo et al., 2021), ototoxic drugs (Breglio et al., 2020), aging (Guo et al., 2021), genetic factors (Fu et al., 2021), and infections (Zhang et al., 2021), among which genetic factors caused $50 \%$ of the hearing loss. GJB2 and GJB6 are two adjacent genes encoding connexin 26 (Cx26) and connexin $30(\mathrm{Cx} 30)$ respectively which form gap junctions (GJs) between supporting cells (SCs) or exist as the hemichannels at the surface of the SCs in the cochlea (Mammano, 2019). 
There are two independent GJ networks identified in the inner ear: the epithelial gap junctional network in the organ of Corti and the connective tissue gap junctional network in the cochlear lateral wall (Kikuchi et al., 1995).

Auditory development depends not only on the functional maturation of cochlear hair cells (HCs) but also on the normal differentiation and organization of nonsensory SCs. SCs are coupled through Cx26 and/or Cx30 GJ channels or hemichannels to form a supporting cell network, transmit ATP, ions, signals, and nutrient molecules (Bruzzone et al., 1996; Jagger and Forge, 2015; Verselis, 2019), and the microenvironment of surrounding HCs (Chen et al., 2018). ATP triggers cytosolic $\mathrm{Ca}^{2+}$ concentration oscillations and propagation of intercellular $\mathrm{Ca}^{2+}$ waves, which appear to play a crucial role in the normal development of the cochlear sensory epithelium, hearing acquisition and the functional maturation of HCs (Johnson et al., 2017; Mammano and Bortolozzi, 2018; Mazzarda et al., 2020). Chai et al. (He et al., 2017; Zhang et al., 2020a,b; Zhang Y. et al., 2020) further confirmed that regenerating HCs cannot achieve functional maturity in the absence of a normal and stable microenvironment by SCs.

GJB2 and GJB6 mutations account for up to $50 \%$ of all nonsyndromic hearing loss cases (Denoyelle et al., 1997; Estivill et al., 1998; Mishra et al., 2018). Homozygous Cx26 and Cx30 deletions lead to severe hearing loss in animal models (Kelsell et al., 1997; del Castillo et al., 2002). It has been reported that $\mathrm{Cx} 26$ and $\mathrm{Cx} 30$ are both important for hearing development (Adadey et al., 2020). Notably, Cx30 knockout mice displayed severe hearing loss in the absence of endocochlear potential, accompanied by a 90\% reduction in Cx26 (Teubner et al., 2003; Boulay et al., 2013). Over-expression of Cx26 in Cx30 knockout mice rescued hearing (Ahmad et al., 2007), but not vice versa (Qu et al., 2012). These results indicated that Cx26 is critical for hearing development since it could not be substituted by $\mathrm{Cx} 30$ in early cochlear development. Cx30-deficient mice with nearly $50 \%$ Cx26 expression showed normal hearing (Boulay et al., 2013). Therefore, the role of $\mathrm{Cx} 30$ in the cochlea remains controversial.

In this study, we used CRISPR/Cas9 technology to establish a novel Cx30 knockout mouse model $\left(\mathrm{Cx} 30^{-/-}\right)$, which preserved approximately $70 \%$ of $\mathrm{Cx} 26$ expression in the cochlea and displayed mild hearing loss under full frequency. This new genotype model showed different morphological and functional phenotypes from the past. We believe that this model is of significant importance to explore the mechanism of hearing loss caused by $\mathrm{Cx} 30$ deletion.

\section{MATERIALS AND METHODS}

\section{Creation and Genotyping of Cx30 Knockout Mice}

$\mathrm{Cx} 30$ knockout mice $\left(\mathrm{C} \times 30^{-/-}\right)$maintained on a pure C57BL/6 background were purchased from the Shanghai Model Organisms. CRISPR/Cas9 technology was used to repair the mutation introduced by non-homologous recombination, resulting in the shift of the protein reading frame of the Gjb6 Exon 3 gene and loss of function. The mouse genotyping was identified by PCR amplification with the following primers: Gjb6 primer 1 (P1) 5'-CTAGTGCAACAGCACCCGTA3', Gjb6 P2 5'-CTAGTGCTGAAGGTGTGGGG-3',Gjb6 P3 5'-TGGCATTGTTTCACCGTAGT-3', Gjb6 P4 $5^{\prime}$ AGGTCATGTGAATCTGTCTC-3', Wild type (WT): Gjb6 P1 and P2 PCR to obtain a single 2369 bp band; Gjb6 P3 and P4 can obtain a 512 bp band; Heterozygous (HE): Gjb6 P1 and P2 PCR to obtain both 527 bp and 2,369 bp bands; Gjb6 P3 and P4 to obtain 512 bp band; Homozygous (HO): Gjb6 P1 and P2 PCR obtained a single 527 bp band; Gjb6 P3 and P4 could not obtain a band. The WT littermates served as controls in the experiment. The experimental procedures were approved by the Shanghai Xinhua Hospital's Animal Center and conducted according to the standards of the NIH Guidelines for the Care and Use of Laboratory Animals.

\section{Assessment of Hearing Loss}

Auditory brainstem response (ABR) reflects the electrical response of the cochlear ganglion neurons and the nuclei of the central auditory pathway to sound stimulation. Their threshold assesses the cochlear sensitivity and it is visually measured according to the occurrence of Wave II in a series of repeatable ABR responses obtained at various sound intensities. After 1, 3, and 6-month-old littermates were anesthetized with ketamine $(80 \mathrm{mg} / \mathrm{kg})$ and xylazine $(10 \mathrm{mg} / \mathrm{kg})$, they were subjected to sudden tones of various frequencies from 4 to $32 \mathrm{kHz}$ (duration of $10 \mathrm{~ms}$, rising -The fall time is $0.5 \mathrm{~ms}$ ). The sound is generated by Tucker-Davis System II hardware and software (Tucker-Davis Technologies, Alachua, FL).

\section{Quantitative PCR Analyses}

Total RNA was extracted from the whole dissected cochlea, the basemental membrane (BM), or the stria vascularis (SV) of postnatal day 5 ( $\mathrm{P} 5$, where $\mathrm{P} 0$ is the date of birth) and 1-monthold mice using the Takara MiniBEST Universal RNA Extraction Kit (Takara, 9767, Japan). Reverse transcription was performed using $1 \mu \mathrm{g}$ of RNA. Quantitative PCR (qPCR) was conducted on cDNAs using. The primers used are as follows:

Cx30 primers: Forward 5'-AAGACCTGGAGGACATCAAA CG- $3^{\prime}$ and

Reverse 5' -CGAAATGAAGCAGTCCACGAG-3'

Cx26 primers: Foward 5' -TCACAGAGCTGTGCTATTTG-3' and

Reverse 5'-ACTGGTCTTTTGGACTTTCC-3'

Actin primers: Foward $5^{\prime}$-GAGAGGGAAATCGTGCGT GA-3' and

Reverse 5' -ACATCTGCTGGAAGGTGGAC-3'), using TB Green ${ }^{\circledR}$ Premix Ex Taq ${ }^{\text {TM }}$ (Takara, RR420B, Japan). Samples were analyzed in triplicate on Applied Biosystems 7500 (ThermoFisher). The expression levels of mRNAs were calculated by the $2^{-\Delta \Delta C T}$ method.

\section{Western Blot Analysis}

Proteins were extracted from the whole dissected cochlea, the BM, or the SV of P5 and 1-month-old mice. The proteins were separated by SDS-PAGE and transferred to PVDF membranes (Millipore, Billerica, MA, USA). The membranes were blocked with 5\% skim milk (Beyotime, Shanghai, China) 
at room temperature for $1 \mathrm{~h}$ and then incubated with primary antibodies against Tublin (Zen Bioscience, 330628, 1:1,000, China), Cx30 antibody (Invitrogen, 71-2800, 1:200, USA), and Cx26 antibody (Invitrogen, 33-5800, 1:200, USA) at $4^{\circ} \mathrm{C}$ overnight. After three times of washing with PBS-0.01\% Tween 20 (PBS-T), the membranes were incubated with a secondary antibody, anti-rabbit IgG, or antimouse IgG (Beyotime; 1:1,000, China), for $2 \mathrm{~h}$ at $37^{\circ} \mathrm{C}$. After washing the membranes, and adding freshly prepared chemiluminescence solution (Millipore; $A: B=1: 1)$, the immunoreactive bands were imaged under the Bio-Rad ChemiDoc XRS+ (Bio-Rad Co., Hercules, CA, USA). Semiquantitative densitometric analysis was performed with ImageJ software.

\section{Immunohistochemistry and Confocal Imaging}

Cochleas of P5 and 1-month-old mice were fixed with $4 \%$ paraformaldehyde, decalcified, frozen, and cut by a cryostat. The tissue sections were directly mounted onto glass slides for staining and storage. The cochlear section was incubated in a blocking solution ( $10 \%$ goat serum and $1 \%$ BSA in the PBS) with $0.1 \%$ Triton $\mathrm{X}-100$ for $1 \mathrm{~h}$ at room temperature. Then, the section was incubated with rabbit anti-Cx30 antibody (Invitrogen, 71-2800, 1:200, USA), the rabbit anti-Cx26 antibody (Invitrogen, 51-2800, 1:200, USA), or the mouse anti-Cx26 antibody (Invitrogen, 33-5800, 1:200, USA) in the blocking solution at $4{ }^{\circ} \mathrm{C}$ overnight, following reaction with corresponding Alexa Fluor 488-, 458- or 647- secondary antibodies (Invitrogen, $1: 500$, USA) for $2 \mathrm{~h}$ at room temperature $\left(23^{\circ} \mathrm{C}\right)$. The sections were further stained by $1 \%$ 40, 6-diamidino-2-phenylindole (DAPI, Invitrogen, 1:200, USA) for $\sim 10 \mathrm{~min}$ or AlexaFluor 568 phalloidin (Servicebio, G1041, 1:500) for $\sim 15$ min following the 2nd antibody incubation to visualize cell nuclei or F-Actin. After washout, the sections were mounted and observed under a microscope.

\section{ATP Release Measurement}

The P5 mouse temporal bone was micro-dissected in ice-cold HBSS (Thermo Fisher Scientific). The inner ear was opened from its apex to base. After removal of the bone, the exposed BM and SV were dissected separately and put into an incubation chamber. For testing ATP release, the isolated $\mathrm{BM}$ and SV was incubated in a zero $\mathrm{Ca}^{2+}$ solution (ZCS) containing (in $\mathrm{mM}$ ): $137 \mathrm{NaCl}, 5.36 \mathrm{KCl}, 0.44 \mathrm{KH} 2 \mathrm{PO} 4$, 0.18 Na2HPO4, 0.1 EGTA, 25 HEPES, and 5.55 Dextrose $(\mathrm{pH}$ 7.3). To quantify ATP release, the BM and SV were incubated in ZCS for $20 \mathrm{~min}$ at $37^{\circ} \mathrm{C}, 5 \% \mathrm{CO} 2$. The collected incubation solutions were kept on ice. The amount of ATP was measured by a bioluminescence method with a luciferinluciferase assay kit (FL-ASC, Sigma, USA) using a black 96-well plate to avoid optical cross-talk. The bioluminescence was read by a Biotek Synergy 4 Hybrid Microplate Reader (Biotek Instruments Inc, Winooski, VT, USA). All bioluminescence measurements reported in this article fell within the linearity range of the ATP standard curve generated according to the manufacturer's instructions.

\section{Measurement of Endocochlear Potential}

The endocochlear potential was recorded under general anesthesia on $\mathrm{Cx} 30^{-/-}(n=6)$ mice and Wt $(n=6)$ mice at 1 month-old. Mice were anesthetized with ketamine $(150 \mathrm{mg} / \mathrm{kg}$, IP) and xylazine (6 mg/kg, IP). Body temperature was maintained at $37^{\circ} \mathrm{C}$ on a heating operating table (Harvard Apparatus, 733771). A mouse head holding adaptor (MA-6N, Narishige, Tokyo, Japan) was used to maintain a supine position. A tracheotomy was performed, followed by opening the auditory bulla through a ventral approach to expose the basal turn of the cochlea. A silver chloride reference electrode was placed under the skin. Access to the scala media of the basal turn was obtained by thinning the bone over the spiral ligament and making a small opening with a pick. A micropipette electrode ( $\sim 2 \mu \mathrm{m}$ ) filled with $150 \mathrm{mM} \mathrm{KCl}$ was advanced through the bony aperture into the spiral ligament. Entry of the electrode tip into the endolymph is characterized by transients in recorded potentials. The electrode was advanced until a stable potential was observed. The signal was amplified through a patch-Clamp Amplifier (HEKA EPC 10 USB double, Germany). The DC potentials were recorded via an A-D converter (HEKA EPC 10 USB PROBE 1, Germany).

\section{Transmission Electron Microscope Observation}

After the cochlea of P5 mice was dissected, it was fixed in $2.5 \%$ glutaraldehyde for $24 \mathrm{~h}$ and decalcified with $10 \%$ EDTA for several days. The samples were fixed in $1 \%$ osmic acid for $2 \mathrm{~h}$, dehydrated with acetone, and embedded in 812 resin. After staining the ultrathin sections with alkaline lead citrate and uranyl acetate, the structure of each cochlea under a Hitachi HF5000 transmission electron microscope (Hitachi, Tokyo, Japan) was observed.

\section{Statistics}

Several statistical methods were used to analyze the data. The Kolmogorov-Smirnov test was used to analyze the normality of the distribution. The Student $t$-test compared statistical means. The Mann-Whitney $U$ test was used for non-normal distributions or distributions with different variances. All statistical analyses were performed using SPSS v19.0 (SPSS Inc. Chicago, IL). Mean values are quoted \pm standard error of the mean (s.e.m.) where $p<0.05$ was assumed as statistically significant.

\section{RESULTS}

\section{Deletion of Cx30 in the Cochlea}

In our model, CRISPR/Cas9 technology was used to repair the mutation introduced by non-homologous recombination, resulting in a shift of the protein reading frame of the Gjb6 exon 3 gene and loss of function (Figures 1A,B). To test for Cx30 inactivation, we measured $\mathrm{Cx} 30$ expression in the inner ear by qPCR (Figure 1C). As expected, no Cx30 transcript was detected in $\mathrm{Cx} 30^{-/-}$mice, whereas $\mathrm{Cx} 30^{+/-}$mice displayed a $57.6 \%$ reduction in expression of $\mathrm{Cx} 30$ mRNA compared to $\mathrm{Cx} 30^{+/+}$ (WT) control mice. Consistent with the mRNA results, Western 
A

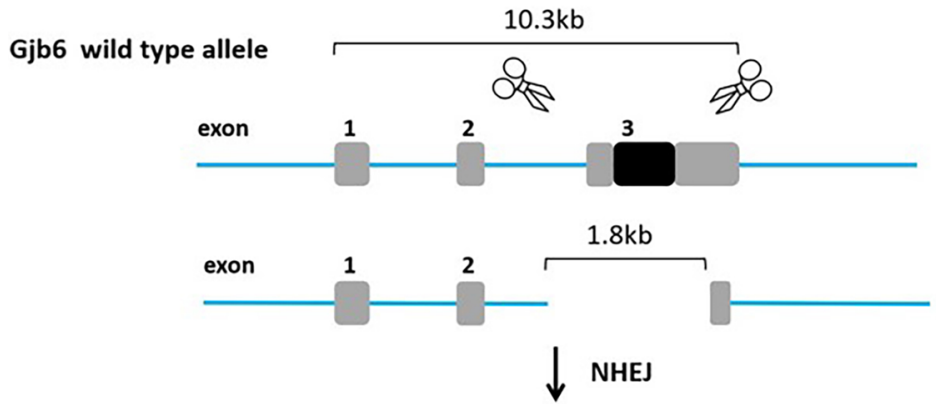

Gjb6 knockout allele
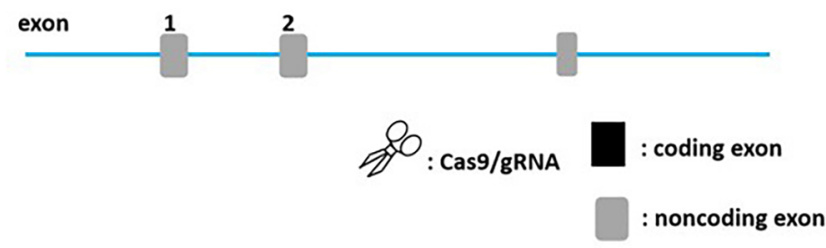

NHEJ: Non-homologous end joining

B

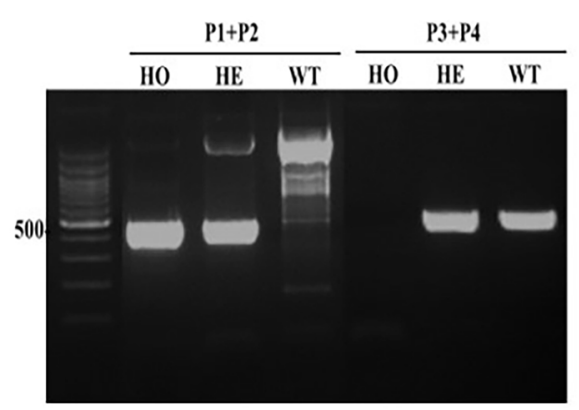

D

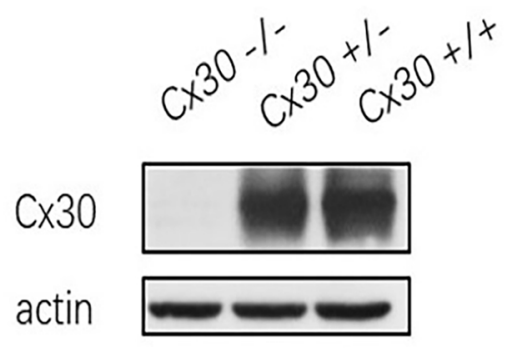

C

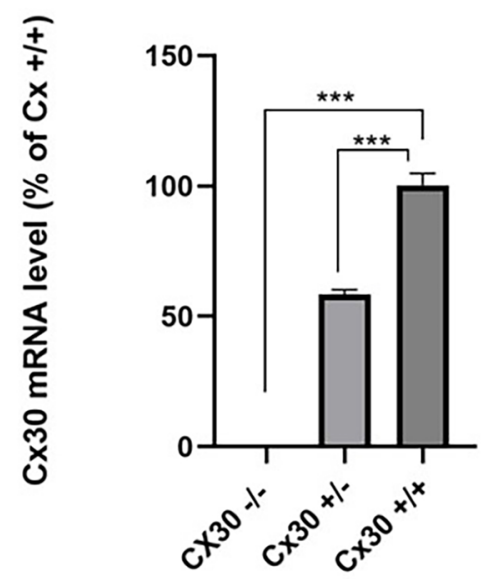

E

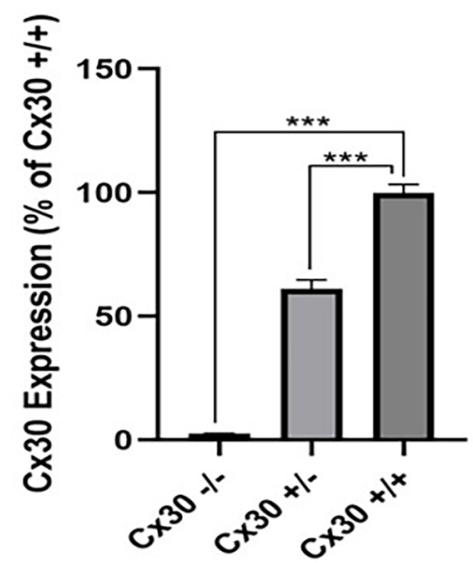

FIGURE 1 | CX30/- mice model. (A) CRISPR/Cas9 technology was used to repair the mutation introduced by non-homologous recombination, resulting in the shift of the protein reading frame of the Gjb6 Exon3 gene. (B) PCR genotyping: Wild type (WT): Gjb6 primer 1 (P1) and P2 PCR to obtain a single 2,369 bp band; Gjb6 P3 and P4 can obtain a 512 bp band; Heterozygous (HE): Gjb6 P1 and P2 PCR to obtain both 527 bp and 2,369 bp bands; Gjb6 P3 and P4 to obtain 512 bp band; Homozygous (HO): Gjb6 P1 and P2 PCR obtained a single 527 bp band; Gjb6 P3 and P4 could not obtain a band. (C-E) Cx30 expression was quantified by qPCR (C) and western blot $(\mathbf{D}, \mathbf{E})$ in the whole cochlea. Data presented as Mean \pm SEM; three independent experiments; three mice of each genotype per experiment; $t$-test. ${ }^{\star \star *} p<0.001$.

blot analysis of protein levels in the inner ear of $\mathrm{Cx} 30+/$ - mice showed a $61.1 \%$ reduction compared to WT mice, while it was undetectable in $\mathrm{Cx} 30^{-/-}$mice (Figures 1D,E).

\section{Hearing Loss in $\mathrm{C} \times 30^{-/-}$Mice}

One-month-old, 3-month-old and 6-month-old Cx30-/- mice displayed mild hearing loss at the full frequency (Figure 2). Compared with WT mice, the ABR thresholds in 1-month-old $\mathrm{C} \times 30^{-/-}$mice at $4,8,11,16,22,32$, and $40 \mathrm{kHz}$ were elevated by $22.7 \pm 2.1(p<0.001), 20 \pm 4.2(p<0.01), 15 \pm 5.9$, $11.3 \pm 3.8(p<0.01), 15.3 \pm 4.2(p<0.05)$, and $6.8 \pm 4.4 \mathrm{~dB}$ SPL, respectively. Compared with WT mice, the ABR thresholds in 3-month-old $\mathrm{Cx} 30^{-/-}$mice at $4,8,11,16,22,32$, and $40 \mathrm{kHz}$ were elevated by $21.8 \pm 2.62(p<0.001), 17 \pm 2.9(p<0.001)$, $18.6 \pm 3.4(p<0.001), 14.3 \pm 2.9(p<0.001), 15 \pm 4.5(p<0.01)$, and $25.5 \pm 3.9(p<0.001) \mathrm{dB}$ SPL, respectively. Compared with
WT mice, the ABR thresholds in 6-month-old $\mathrm{Cx} 30^{-/-}$mice at $4,8,11,16,22,32$, and $40 \mathrm{kHz}$ were elevated by $17.5 \pm 2.9$ $(p<0.01), 35 \pm 2.9(p<0.001), 32.1 \pm 1.7(p<0.001), 33.3 \pm 1.7$ $(p<0.001), 18.3 \pm 4.4$, and $-2.5 \pm 2.9 \mathrm{~dB}$ SPL, respectively. At 6-months of age, the high-frequency hearing thresholds in $\mathrm{C} \times 30^{-/-}$mice and WT mice were nearly identical.

\section{Normal Cochlea Microstructure in $\mathrm{C} \times 30^{-/-}$ Mice}

$\mathrm{C} \times 30^{-/-}$mice had no cochlear developmental disorders (Figure 3). Whole-mounting of the apical, middle, and basal turns of the cochlear sensory epithelium of 1-monthold $\mathrm{C} \times 30^{-1-}$ mice and WT mice showed no apparent hair cell loss (Figures 3A,E). HE staining of cochlear frozen sections in $\mathrm{C} \times 30^{-/-}$mice and WT mice showed no difference in the number of SGNs and the thickness of SV (Figures 3B-D). 

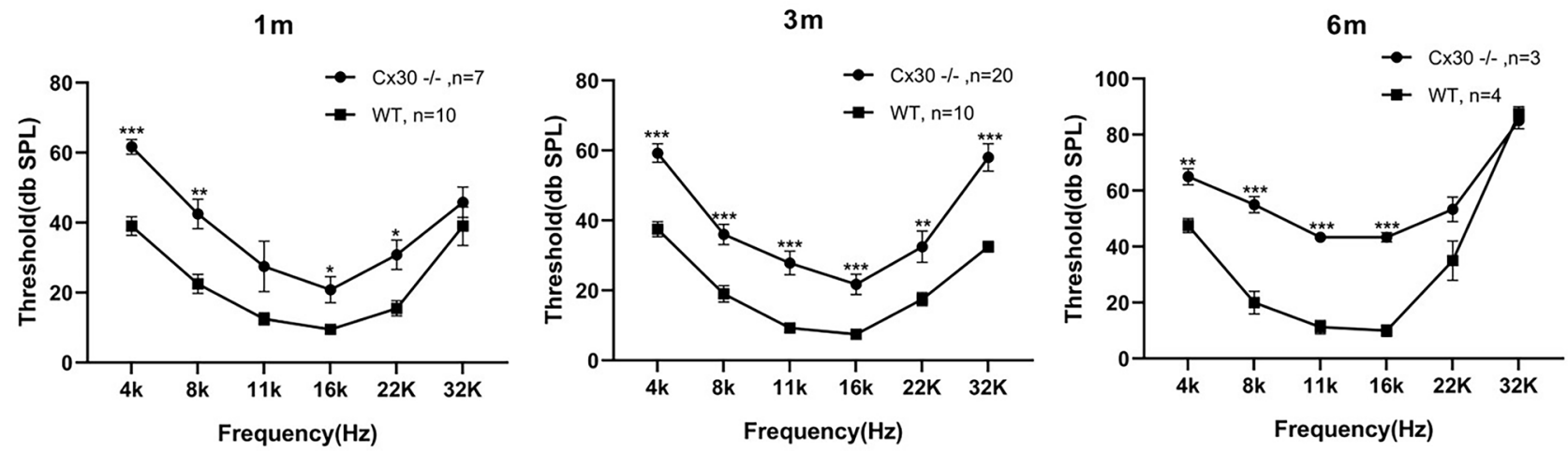

FIGURE 2 | Mild hearing loss in CX30\%- mice. ABR waveforms were recorded from Cx30 $/$ and WT littermate mice at 1 m, 3 m, 6 m. 1 m: 1 -month-old; 3 m: 3-month-old; 6 m: 6-month-old. Data presented as Mean $\pm \mathrm{SEM} ; n>3$ in each group. $t$-test. ${ }^{\star} p<0.05$, ${ }^{* \star} p<0.01$, ${ }^{\star \star \star} p<0.001$. ABR, Auditory brainstem response.

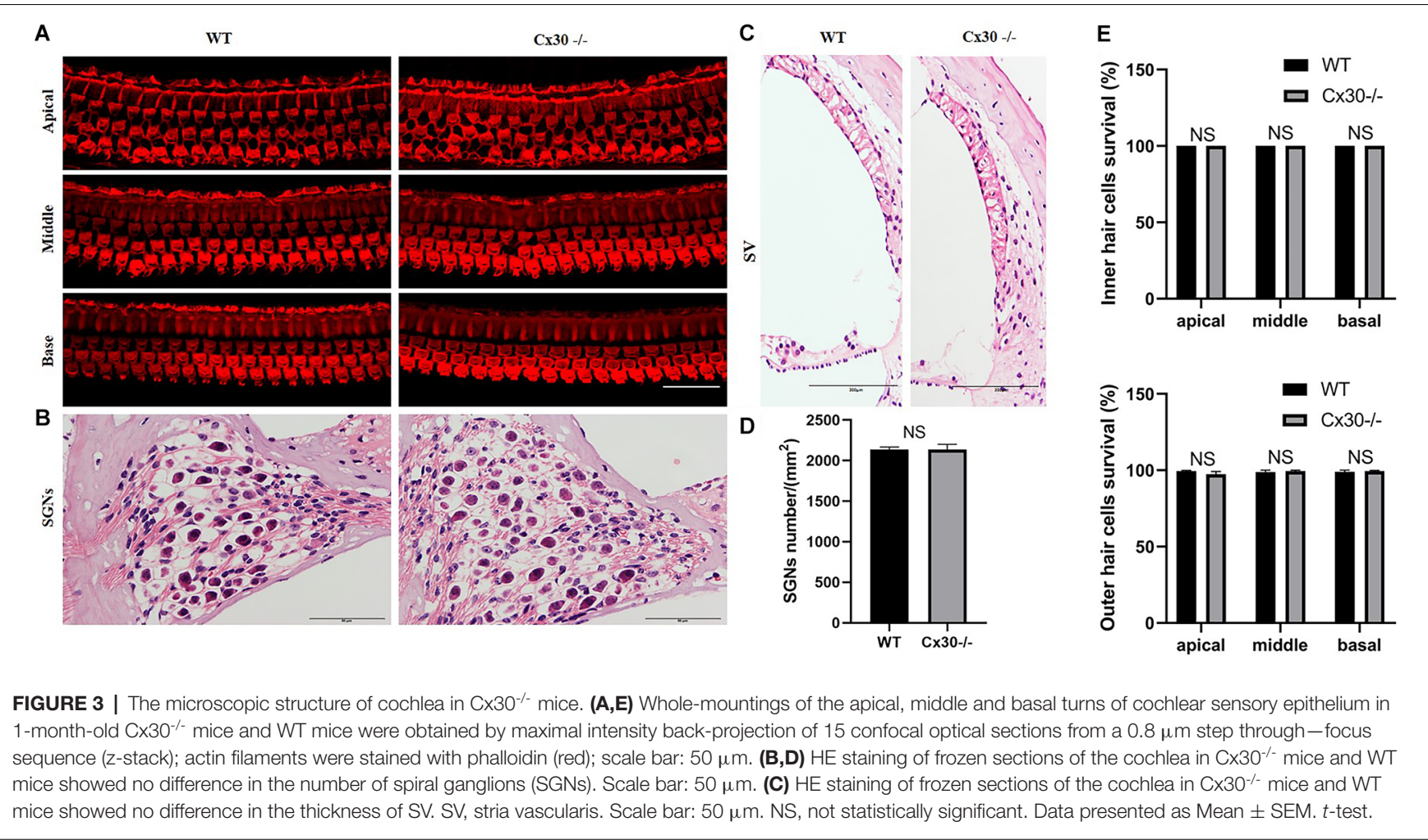

\section{Cx26 Expression in Cx30/- Mice}

Immunofluorescence showed that $\mathrm{Cx} 26$ expression in the $\mathrm{BM}$ of $\mathrm{C} \times 30^{-/}$mice was stronger than that of WT mice, and Cx26 expression in the vascular stripe of $\mathrm{Cx} 30^{-/-}$mice was significantly lower than that of WT mice both in 1-mouthold and P5 (Figures 4A,B).The mRNA and protein levels of $\mathrm{Cx} 26$ in the cochlea of $\mathrm{Cx} 30^{-/-}$mice relative to that of WT mice were quantified (Figures 4C,D). qPCR analysis showed that the whole cochlear Cx26 mRNA levels of 1-month-old Cx30 $0^{-/-}$mice decreased by $41.8 \%$ compared with WT mice; whole cochlear mRNA levels in $\mathrm{Cx} 30^{-/-}$mice decreased by $28 \%$ compared with
WT mice at P5; cochlear BM Cx26 mRNA levels in Cx30/- mice increased by $36.7 \%$ compared with WT mice at P5; cochlear SV Cx26 mRNA levels in Cx30/- mice decreased by $56.6 \%$ compared with WT mice in P5 (Figure 4D). Western blot showed that the whole cochlear Cx26 protein levels in 1-month-old Cx30 $30^{-/}$mice decreased by $25.9 \%$ compared with WT mice; whole cochlear Cx26 protein levels of $\mathrm{Cx} 30^{-/-}$mice reduced by $9.84 \%$ compared with WT mice at $\mathrm{P} 5$; cochlear BM Cx26 protein levels of $\mathrm{Cx} 30^{-/-}$ mice increased by $19.8 \%$ compared with WT mice at P5; cochlear SV Cx26 protein level of $\mathrm{Cx} 30^{-/-}$mice decreased by $25.6 \%$ compared with WT mice in P5 (Figure 4C). 

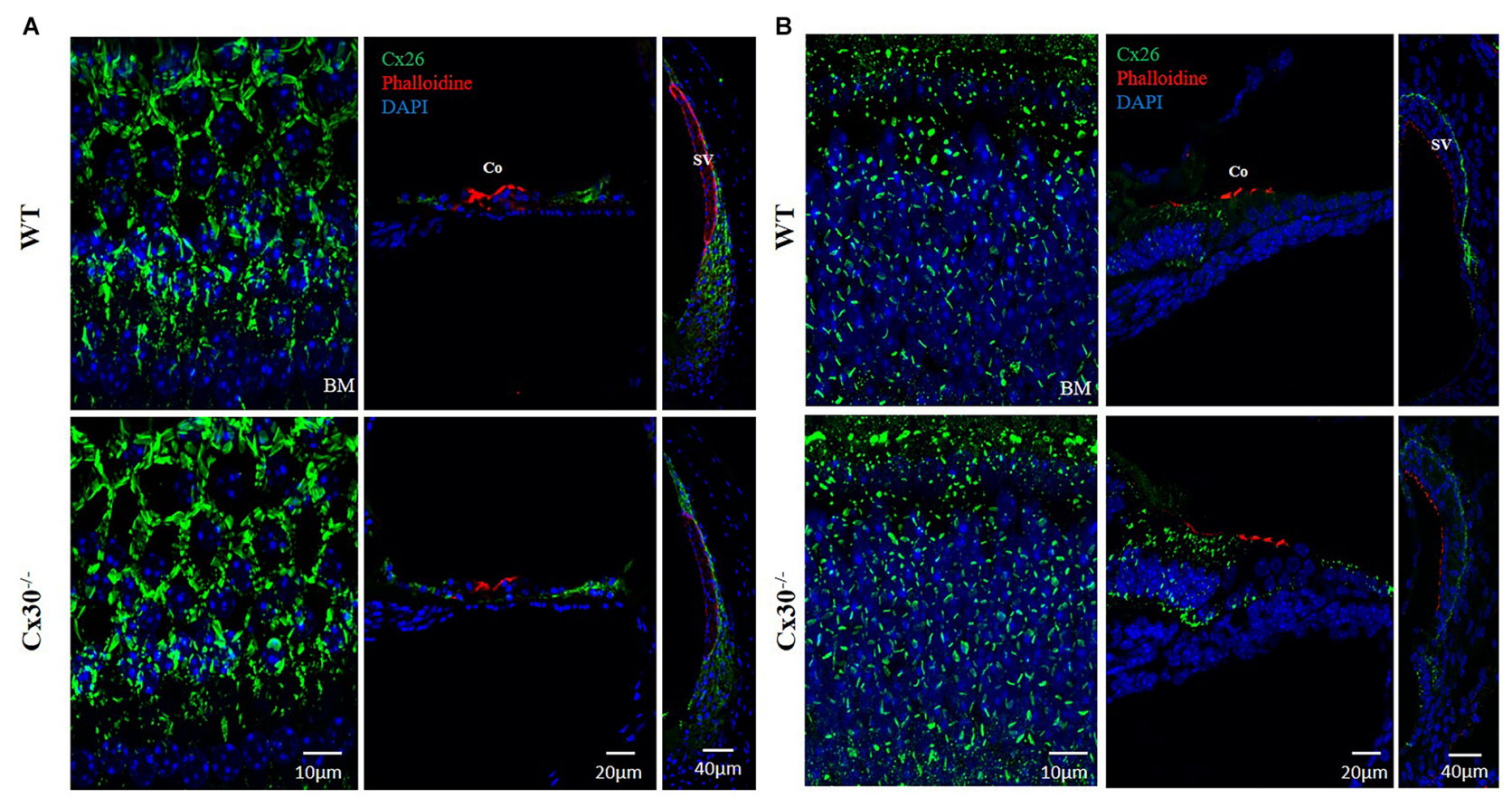

C

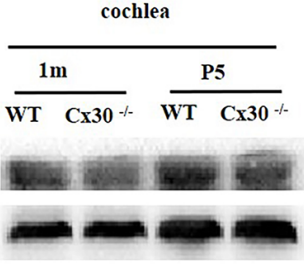

Tublin

$$
\frac{\text { P5 BM }}{{\mathrm{WT} \mathrm{Cx} 30^{-/}}_{\mathrm{WT} \mathrm{Cx} 30^{--}}}
$$

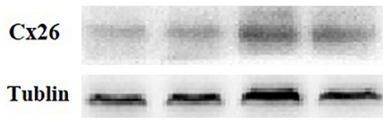

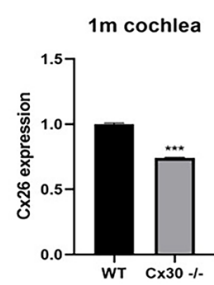

p5 BM

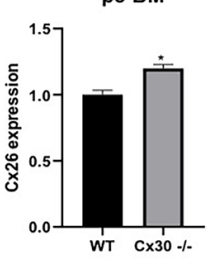

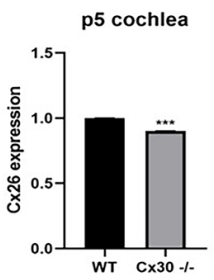

p5 SV

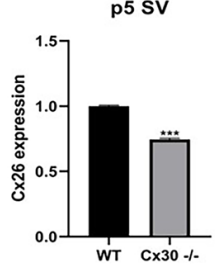

D
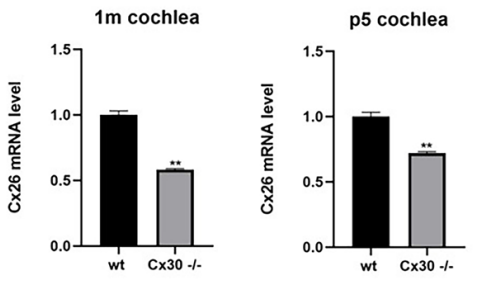

p5 BM

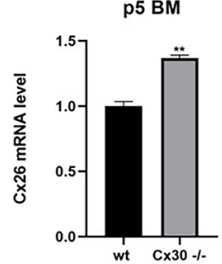

p5 SV

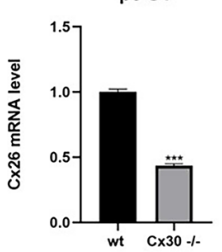

FIGURE 4 | Cx26 expression in Cx30/- mice. (A) Immunofluorescence analysis of frozen sections and BM in the cochlea of 1-month-old mouse. (B) Immunofluorescence analysis of frozen sections and BM in the cochlea at P5. Both in 1-month-old and P5, Cx26 expression in the BM of Cx30 ${ }^{-/-}$mice was stronger than that of WT mice, and Cx26 expression in the vascular stripe of Cx30 $/$ mice was significantly lower than that of WT mice. Cx26: Green, Phalloidin: Red, DAPI: Blue (for cell nuclei); scale bar: $10 \mu \mathrm{m}, 20 \mu \mathrm{m}, 40 \mu \mathrm{m}$. (C) Western blot analysis of the cochlea, BM, and SV in 1-month-old and P5 mice. Whole cochlear Cx26 protein levels in 1-month-old Cx30 $\%$ mice showed a $25.9 \%$ decrease compared with WT mice; whole cochlear Cx26 protein levels of Cx30 $\%$ mice showed 9.84\% reduction compared with WT mice at P5; cochlear BM Cx26 protein levels of Cx30 $\%$ mice increased by $19.8 \%$ compared with WT mice at P5; Cx26 protein level in SV of the cochlea in Cx30\% mice decreased by 25.6\% compared with WT mice in P5. (D) qPCR analysis of the cochlea, BM, and SV in 1-month-old and P5 mice. Whole cochlear Cx26 mRNA levels of 1-month-old Cx30 $\%$ mice declined by $41.8 \%$ compared with WT mice; whole cochlear mRNA levels of Cx30 $\%$ mice decreased by $28 \%$ compared with WT mice at P5; cochlear BM Cx26 mRNA levels in Cx30 $\%$ mice increased by $36.7 \%$ compared with WT mice at P5; cochlear SV Cx26 mRNA levels in Cx30\% mice reduced by 56.6\% compared with WT mice at P5. Data presented as Mean \pm SEM. $t$-test. ${ }^{\star} p<0.05$, ${ }^{\star \star} p<0.01,{ }^{\star \star \star} p<0.001$. BM, basemental membrane; SV, stria vascularis; Co, Corti's organ.

\section{Mild Damaged Stria Vascularis Submicroscopic Structure in $\mathrm{C} \times 30^{-/-}$Mice}

Figure 5 shows the transmission electron microscopy images of the submicroscopic structure of the SV in $\mathrm{C} \times 30^{-/-}$mice. There was some visible vacuolar injury in the $\mathrm{SV}$ of $\mathrm{Cx} 30^{-/}$mice compared with WT mice, which suggested that $\mathrm{Cx} 30$ deletion might cause mild damage to the SV.

\section{Reduction of Endocochlear Potential in Cx $30^{-/-}$Mice}

Figure 6 shows a reduction of EP in 1-month-old Cx30-1- mice compared with the WT mice. EPs in $\mathrm{C} \times 30^{-/-}$mice and WT mice were $80.1 \pm 2.6 \mathrm{mV}$ and $104.6 \pm 1.9 \mathrm{mV}$, respectively (Figure 6B). EP in $\mathrm{Cx} 30^{-1-}$ mice was significantly reduced by $23.4 \%(p<0.001)$ relative to WT mice. 


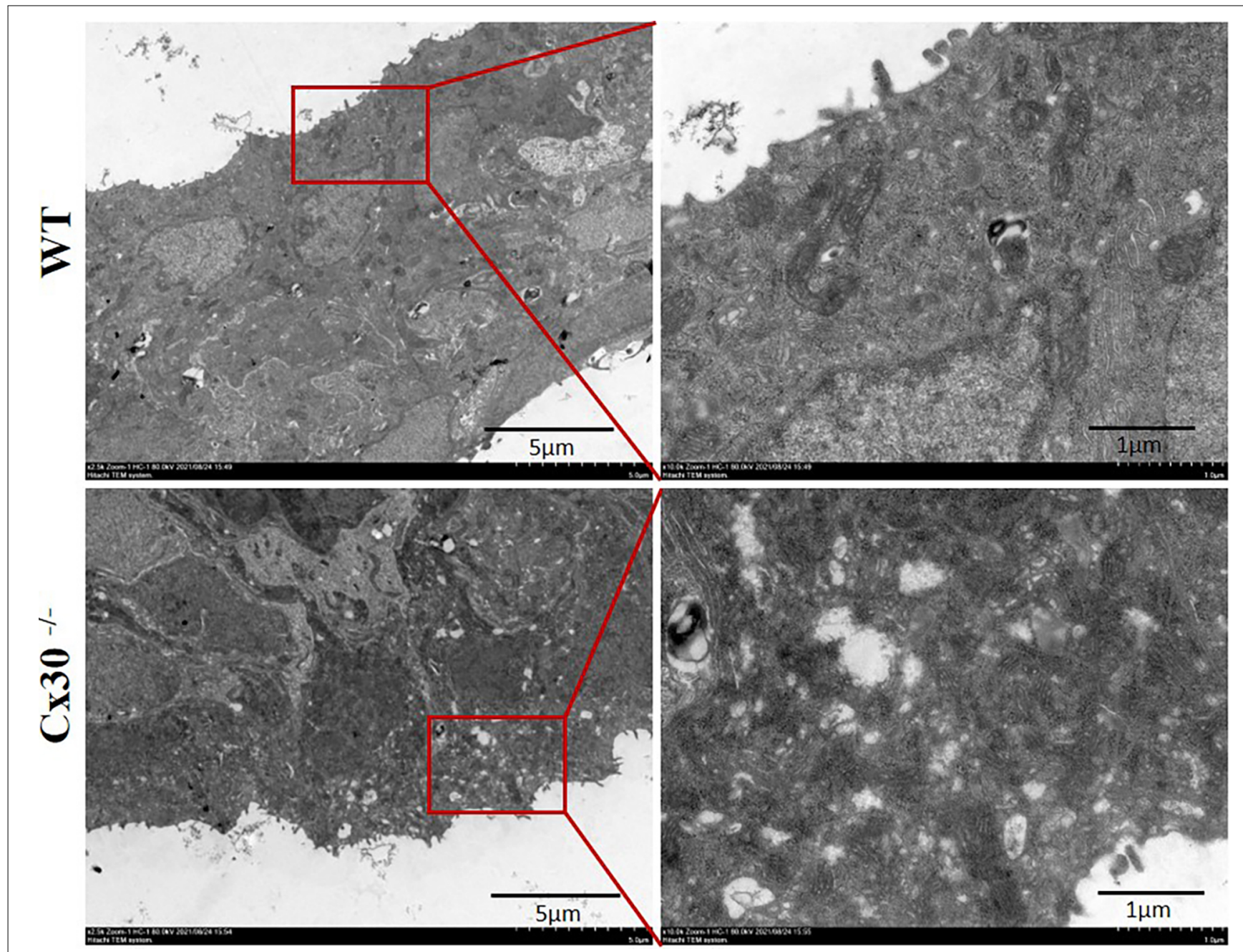

FIGURE 5 | Transmission electron microscopy of the submicroscopic structure of the stria vascularis in Cx30 ${ }^{-/-}$mice. Visible cavity-like damage in the SV of Cx30 ${ }^{-/}$ mice compared with WT mice. Scale bar: $5 \mu \mathrm{m}, 1 \mu \mathrm{m}$.

\section{Reduction of ATP Release in Cx30-/- Mice}

Figure 7 shows reductions in ATP release of $\mathrm{Cx} 30^{-/-}$mice relative to WT mice, both in BM and SV at P5. Compared with WT mice, ATP release in $\mathrm{Cx} 30^{-1-}$ mice was significantly reduced by $14.2 \%$ $(p<0.05)$ in BM and $37.9 \%(p<0.01)$ in SV, respectively. ATP release of SV decreased more significantly than that of BM.

\section{DISCUSSION}

Seven large genomic deletions of GJB6 have been previously reported, including $>920 \mathrm{~kb}$ deletion (Feldmann et al., 2009), $179 \mathrm{~kb}$ deletion (Tayoun et al., 2016), $131 \mathrm{~kb}$ deletion (Wilch et al., 2010), del(GJB6-D13S175), del(GJB6-D13S1830), $\operatorname{del}(G J B 6-D 13 S 1854 ;$ Bliznetz et al., 2017) and $\operatorname{del}(G J B 6-$ D13S1834; Pandya et al., 2020). Homozygous deletion of GJB6 results in severe to profound hearing loss in humans, similar to the mouse model (Teubner et al., 2003; Mei et al., 2017; Pandya et al., 2020). In many cases, the large deletions of GJB6 disrupt a 50 cis-acting element upstream of both genes, which abolishes the expression of GJB2, and hence is responsible for the phenotype (Rodriguez-Paris and Schrijver, 2009). A recent study reported the del (GJB6-D13S1830) deletion in 16.35\% of all GJB2 heterozygotes, which causes more profound hearing loss than those with bi-allelic change in GJB2 (Pandya et al., 2003, 2020; Snoeckx et al., 2005). The more severe audiological findings in digenic probands cannot be explained by the sole theory of a putative cis-regulatory element in the deleted region (Pandya et al., 2020), suggesting that both GJB6 and GJB2 products may contribute to the hearing loss.

The Corti's organ is the core in the auditory system, which is composed of HCs and SCs. SCs release ATP via connexin which triggers intercellular $\mathrm{Ca}^{2+}$ wave propagation and might be critical for the functional maturation of $\mathrm{HCs}$ (Johnson et al., 2017). The function of HCs is to transduce the sound mechanical stimulation into the primary acoustic signals (Abeytunge et al., 2021), while the spiral ganglion neurons (SGNs) transmit primary acoustic information from HCs in the organ of Corti to the higher auditory centers 


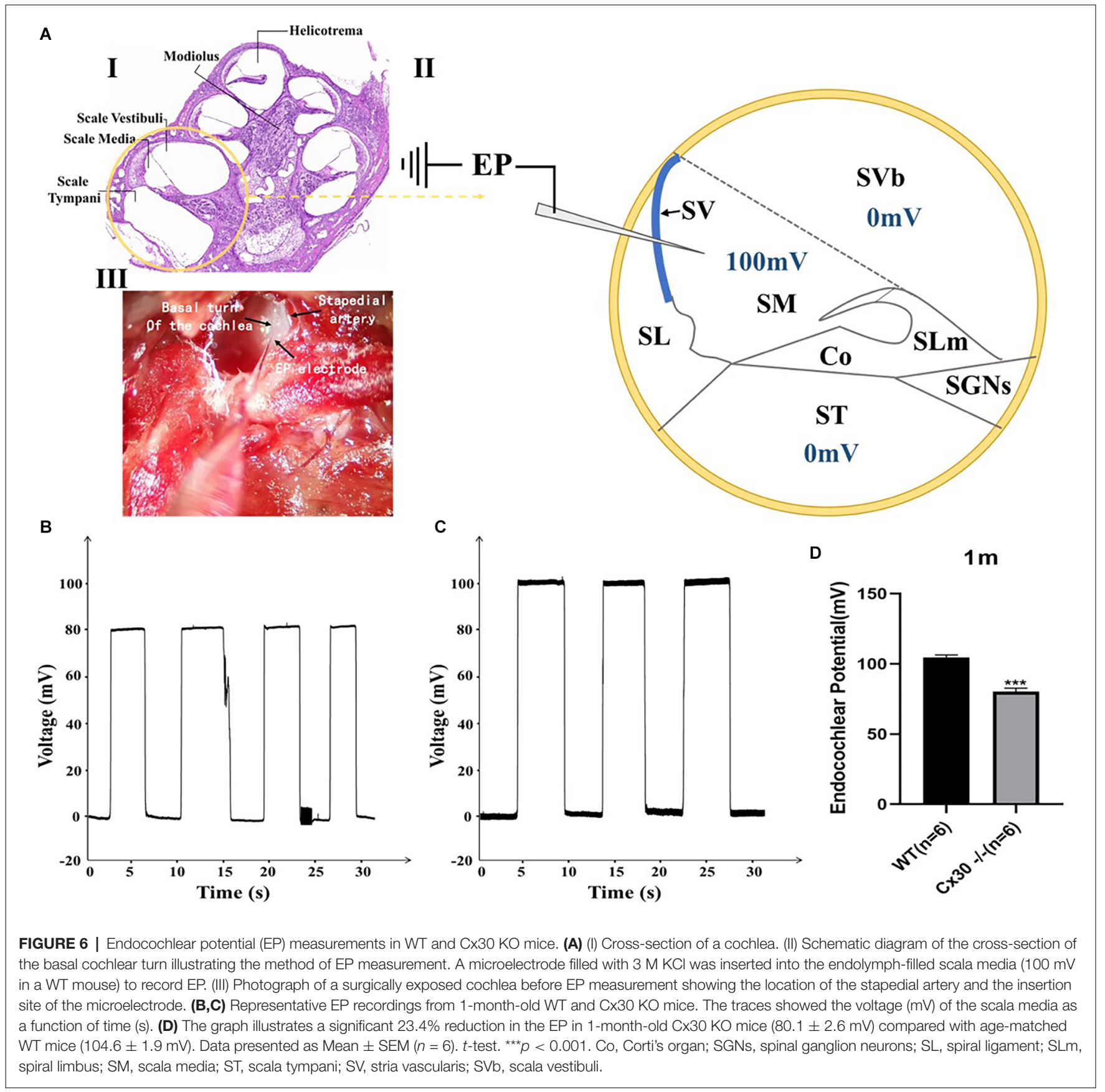

of the central nervous system (Wei et al., 2021). GJB6 and GJB2 are located on the same chromosome (13q12.11) in the human genome. Due to the relative proximity of these two genes, their expressions might be controlled by the same set of regulatory elements (Wilch et al., 2006). Homozygous deletion mutations of either $\mathrm{C} \times 26$ or $\mathrm{Cx} 30$ could cause deafness in humans (Kelsell et al., 1997; del Castillo et al., 2002). Cx26 plays a critical role in auditory function and its deficiency leads to significant hearing loss in the animal model (CohenSalmon et al., 2002; Chen et al., 2014). Cx26 deficiency in the cochlea could cause pathological changes, including cochlear developmental disorders (Wang et al., 2009; Liang et al., 2012),
HCs and SGNs degeneration (Cohen-Salmon et al., 2002; Sun et al., 2009; Wang et al., 2009), EP reduction (Chen et al., 2014), and impairment of active cochlear amplification (Zhu et al., 2013, 2015). HCs and SGNs degeneration was detected around P14 in Cx26-deficient mice (Sun et al., 2009; Wang et al., 2009). However, severe hearing loss precedes substantial hair cell loss after the deletion of Cx26 (Liang et al., 2012). Nevertheless, EP remained normal after targeted deletion of Cx26 expression in Deiters SCs and outer pillar SCs, which are located around OHCs in the cochlear sensory epithelium (Zhu et al., 2013). This indicates that impairment of the cochlear sensory GJ network may not affect EP generation in the inner 


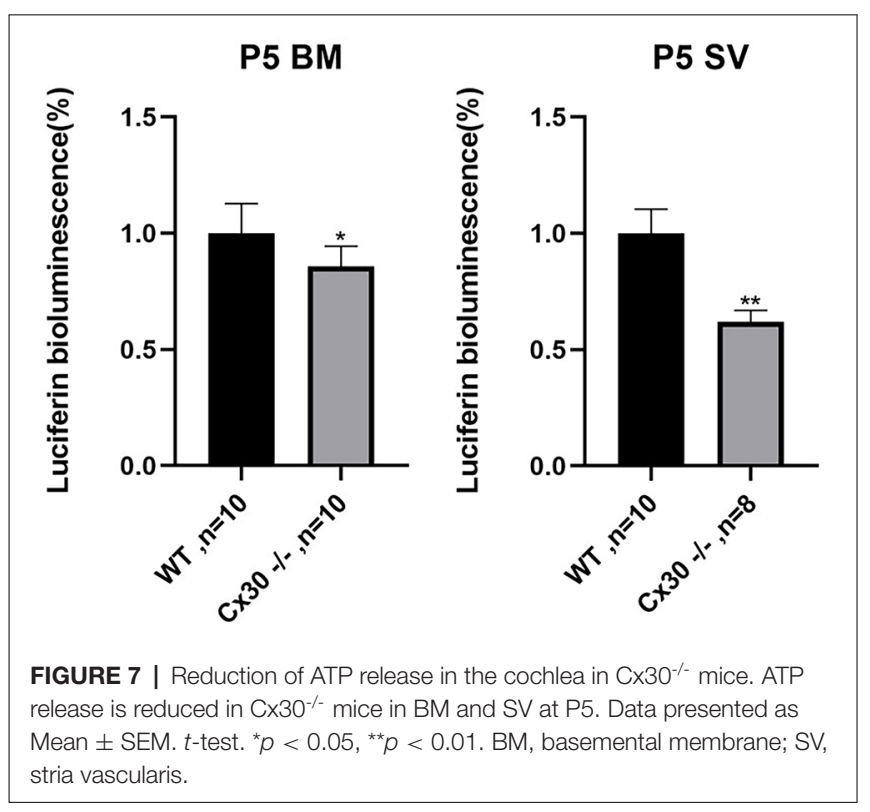

ear (Zhu et al., 2013; Chen and Zhao, 2014; Chen et al., 2015). However, Cx26 deficiency in the cochlear SCs can affect OHC electromotility and active cochlear amplification, since distortion product otoacoustic emission (DPOAE) was reduced ( $\mathrm{Yu}$ and Zhao, 2009; Zhu et al., 2013, 2015). On the other hand, the cochlear tunnel opens from P5 (Kraus and Aulbach-Kraus, 1981). Cx26 deficiency before P5 can lead to occlusion of the cochlear tunnel and induce cochlear developmental disorders with congenital deafness (Chen et al., 2014). Nevertheless, cochlear development proceeded normally, the cochlear tunnel opened normally, and hearing remained normal at a young age after deletion of Cx26 after P5 (Chen et al., 2014). These findings suggest that $\mathrm{Cx} 26$ expression in the cochlea at the early postnatal development stage is critical for cochlear postnatal development and maturation.

Teubner et al. (2003) found that Cx30 knockout mice display severe hearing loss with the absence of EP. Whether the Cx30 deficiency itself or the accompanying significant decrease of Cx26 (approximately 90\%) leads to hearing loss in this model remains unknown. Restoration of Cx26 protein level in the cochlea completely rescues hearing in $\mathrm{Cx} 30$ knockout mice, whereas hearing loss in the conditional Cx26 (cCx26) null mice could not be rescued by genetically over-expressing Cx30 (Ahmad et al., 2007; Qu et al., 2012). Cx26 protein expression preceded that of Cx30, and Cx26 is the only and essential GJ protein detected by immunolabeling in the organ of Corti during the early postnatal period (Qu et al., 2012). During the postnatal development, the lack of GJs in the Corti's organ leads to obstacles in intercellular material transport and communication, and failure of Corti's organ to mature, leading to hearing loss. However, the $\mathrm{Cx} 26$ expression of $\mathrm{BM}$ increased in $\mathrm{Cx} 30^{-/-}$mice at the early postnatal period (P5) in the present study.

Boulay et al. (2013) established $\mathrm{Cx} 30^{\mathrm{fl} / \mathrm{fl}}$ mice, and found no significant difference in hearing between $\mathrm{Cx} 30^{\mathrm{fl} / \mathrm{fl}}$ mice and WT mice, however, Cx26 was decreased to $35 \%$ and $\mathrm{Cx} 30$ was reduced to $64 \%$. Normal EP and DPOAE were observed in this kind of mice (Boulay et al., 2013). Crossing Cx30 $0^{\mathrm{fl} / \mathrm{fl}}$ mice with Pgk-Cre mice generated $\mathrm{Cx} 30^{\Delta / \Delta}$ mice to delete $\mathrm{Cx} 30$, which exhibited no hearing loss, while Cx26 was decreased to $52 \%$ (Boulay et al., 2013). The threshold level of Cx26 decline in $\mathrm{Cx} 30$-deficient mice that causes hearing loss remains unclear. The $\mathrm{C} \times 30^{-/-}$mice established in this study exhibited only mild hearing loss, while cochlear Cx26 decreased to $74 \%$. Since Cx26 did not show any major decrease through Cx30 knockout, the mechanism of hearing loss needs to be further explored.

The high positive potential of EP is critical for animal hearing and develops rapidly in the days before the onset of hearing (P4-P11; Chen et al., 2015). EP $(+100-110 \mathrm{mV})$ is the driving force for the generation of auditory receptor currents and potentials by $\mathrm{K}^{+}$ions through transduction channels in the HCs, which are formed by a complex process in the SV of the cochlea. The widely accepted "two-cell" model suggests that EP production begins in the fibroblasts of the spiral ligament. Type II fibroblasts depolarize the cells to $\sim 5 \mathrm{mV}$ via $\mathrm{Na}^{+} / \mathrm{K}^{+}$- ATPase and $\mathrm{Na}^{+}, \mathrm{K}^{+}, 2 \mathrm{Cl}^{-}$cotransport proteins. The intermediate cells of the SV are subsequently coupled by $\mathrm{Cx} 26$ and $\mathrm{Cx} 30$ via GJs. Thereafter, the ATP-dependent Kir4.1 $\mathrm{K}^{+}$channel on the apical membrane of intermediate cells (Ando and Takeuchi, 1999; Liu and Zhao, 2008; Nin et al., 2008) generates a $105-110 \mathrm{mV}$ transmembrane potential (Nernst's $\mathrm{K}^{+}$balance potential) between the intracellular space and the intrastriatal space. This positive intrastriatal potential eventually leads to EP positivity in the middle-grade endolymph. The network of two GJs composed of Cx26 and Cx30 forms a pathway through which $\mathrm{K}^{+}$ions that pass through sensory cells during mechanosensory transmission can be recirculated into the endolymphatic space such that they re-enter sensory cells (Wangemann, 2002). GJs deficiency may lead to the obstruction of $\mathrm{K}^{+}$circulation, thus affecting the formation of EP and hearing. ATP is necessary for EP generation and $\mathrm{K}^{+}$recycling (Zhu and Zhao, 2010; Chen et al., 2015). The perfusion of ATP into the cochlea can significantly increase EP (Sueta et al., 2003). As described above, depolarization of fibroblasts by co-activation of $\mathrm{Na}^{+} / \mathrm{K}^{+}$- ATPase and $\mathrm{Na}^{+}$, $\mathrm{K}^{+}, 2 \mathrm{Cl}^{-}$-cotransporters is the first step in EP production. Although $\mathrm{Na}^{+} / \mathrm{K}^{+}$- ATPase is primarily driven by intracellular ATP, extracellular ATP can stimulate $\mathrm{Na}^{+} / \mathrm{K}^{+}$- ATPase activity by activating purinergic receptor and Src family kinase (SFK) as well (Shahidullah et al., 2012). In addition, the function of the primary active $\mathrm{Na}^{+} / \mathrm{K}^{+}$- ATPase requires $\mathrm{K}$-channel coupling to recycle $\mathrm{K}^{+}$(Muto et al., 2003). This "pump coupling" was proposed in 1958, and was subsequently confirmed by experimental data (Koefoed-Johnsen and Ussing, 1958; Dawson and Richards, 1990; Tsuchiya et al., 1992). Recently, it was found that extracellular ATP can also activate ATP-sensitive (KIR) $\mathrm{K}$ channels in hippocampal CA3 pyramidal neurons and lung epithelial cells, which cooperate with $\mathrm{Na}^{+} / \mathrm{K}^{+}$ATPase activity. ATP may initially activate the P2X receptor and subsequently activate the KIR potassium channel and $\mathrm{Na}^{+} / \mathrm{K}^{+}$- ATPase (Telang et al., 2010; Jiang et al., 2013; Schmid and Evans, 2019).

In this study, we established a novel Cx30 complete knockout mouse model, with a mild full-frequency hearing loss as indicated 
by ABR. The protein level of Cx 26 was decreased by less than $30 \%$ in the cochlea of these mice, which was significantly different from the previous Cx30-deficient mouse model. Moreover, both EP and ATP release showed a decreasing trend in the present mouse model. These results suggest that $\mathrm{Cx} 30$ may play an important role in hearing development, however, further investigation on the underlying mechanism is needed in the future.

\section{DATA AVAILABILITY STATEMENT}

The original contributions presented in the study are included in the article, further inquiries can be directed to the corresponding author/s.

\section{ETHICS STATEMENT}

The animal study was reviewed and approved by the Ethics Committee of Xin Hua Hospital Affiliated to Shanghai Jiao Tong University School of Medicine (XHEC-2021-636).

\section{REFERENCES}

Abeytunge, S., Gianoli, F., Hudspeth, A. J., and Kozlov, A. S. (2021). Rapid mechanical stimulation of inner-ear hair cells by photonic pressure. eLife 10:e65930. doi: 10.7554/eLife.65930

Adadey, S. M., Wonkam-Tingang, E., Twumasi Aboagye, E., Nayo-Gyan, D. W., Boatemaa Ansong, M., Quaye, O., et al. (2020). Connexin genes variants associated with non-syndromic hearing impairment: a systematic review of the global burden. Life (Basel) 10:258. doi: 10.3390/life10110258

Ahmad, S., Tang, W., Chang, Q., Qu, Y., Hibshman, J., Li, Y., et al. (2007). Restoration of connexin26 protein level in the cochlea completely rescues hearing in a mouse model of human connexin30-linked deafness. Proc. Natl. Acad. Sci. U S A 104, 1337-1341. doi: 10.1073/pnas.0606855104

Ando, M., and Takeuchi, S. (1999). Immunological identification of an inward rectifier $\mathrm{K}+$ channel (Kir4. 1) in the intermediate cell (melanocyte) of the cochlear stria vascularis of gerbils and rats. Cell Tissue Res. 298, 179-183. doi: $10.1007 / \mathrm{s} 004419900066$

Bliznetz, E. A., Lalayants, M. R., Markova, T. G., Balanovsky, O. P., Balanovska, E. V., Skhalyakho, R. A., et al. (2017). Update of the GJB2/DFNB1 mutation spectrum in Russia: a founder Ingush mutation $\operatorname{del}(\mathrm{GJB} 2-\mathrm{D} 13 \mathrm{~S} 175)$ is the most frequent among other large deletions. J. Hum. Genet. 62, 789-795. doi: 10.1038/jhg.2017.42

Boulay, A. C., del Castillo, F. J., Giraudet, F., Hamard, G., Giaume, C., Petit, C., et al. (2013). Hearing is normal without connexin30. J. Neurosci. 33, 430-434. doi: 10.1523/JNEUROSCI.4240-12.2013

Breglio, A. M., May, L. A., Barzik, M., Welsh, N. C., Francis, S. P., Costain, T. Q., et al. (2020). Exosomes mediate sensory hair cell protection in the inner ear. J. Clin. Invest. 130, 2657-2672. doi: 10.1172/JCI128867

Bruzzone, R., White, T. W., and Paul, D. L. (1996). Connections with connexins: the molecular basis of direct intercellular signaling. Eur. J. Biochem. 238, 1-27. doi: 10.1111/j.1432-1033.1996.0001q.x

Chen, J., Chen, J., Zhu, Y., Liang, C., and Zhao, H. B. (2014). Deafness induced by Connexin 26 (GJB2) deficiency is not determined by endocochlear potential (EP) reduction but is associated with cochlear developmental disorders. Biochem. Biophys. Res. Commun. 448, 28-32. doi: 10.1016/j.bbrc.2014. 04.016

Chen, S., Xu, K., Xie, L., Cao, H.-Y., Wu, X., Du, A.-N., et al. (2018). The spatial distribution pattern of Connexin26 expression in supporting cells and its role in outer hair cell survival. Cell Death Dis. 9:1180. doi: 10.1038/s41419-018 $-1238-x$

\section{AUTHOR CONTRIBUTIONS}

JC: experimental implementation, data quality control, and wrote the manuscript. PC: immunohistochemical staining and statistical data analysis. BH: western blot and qPCR. TG: qPCR experiments. YL: collection of cochlear samples for TEM experiments. JZ: collection of cochlear samples for H\&E experiments. JL: collection of cochlear samples for TEM experiments. FM: EP experiments. $\mathrm{SH}$ : research conception and experimental supervision. JY: research conception, manuscript review and revision. All authors contributed to the article and approved the submitted version.

\section{FUNDING}

This work was sponsored by grants from the National Natural Science Foundation of China-China Academy of General Technology Joint Fund for Basic Research (81873698, 82000977) and Shanghai Sailing Program (20YF1428900).

Chen, J., and Zhao, H. B. (2014). The role of an inwardly rectifying $\mathrm{K}(+)$ channel (Kir4.1) in the inner ear and hearing loss. Neuroscience 265, 137-146. doi: 10.1016/j.neuroscience.2014.01.036

Chen, J., Zhu, Y., Liang, C., Chen, J., and Zhao, H.-B. (2015). Pannexin1 channels dominate ATP release in the cochlea ensuring endocochlear potential and auditory receptor potential generation and hearing. Sci. Rep. 5:10762. doi: 10.1038/srep10762S

Cohen-Salmon, M., Ott, T., Michel, V., Hardelin, J. P., Perfettini, I., Eybalin, M. et al. (2002). Targeted ablation of connexin26 in the inner ear epithelial gap junction network causes hearing impairment and cell death. Curr. Biol. 12, 1106-1111. doi: 10.1016/s0960-9822(02)00904-1

Dawson, D. C., and Richards, N. W. (1990). Basolateral K conductance: role in regulation of $\mathrm{NaCl}$ absorption and secretion. Am. J. Physiol. 259, C181-C195. doi: 10.1152/ajpcell.1990.259.2.C181

del Castillo, I., Villamar, M., Moreno-Pelayo, M. A., del Castillo, F. J. Alvarez, A., Telleria, D., et al. (2002). A deletion involving the connexin 30 gene in nonsyndromic hearing impairment. N. Engl. J. Med. 346, 243-249. doi: 10.1056/NEJMoa012052

Denoyelle, F., Weil, D., Maw, M. A., Wilcox, S. A., Lench, N. J., Allen-Powell, D. R. et al. (1997). Prelingual deafness: high prevalence of a 30delG mutation in the connexin 26 gene. Hum. Mol. Genet. 6, 2173-2177. doi: 10.1093/hmg/6.12.2173

Estivill, X., Fortina, P., Surrey, S., Rabionet, R., Melchionda, S., D’Agruma, L., et al. (1998). Connexin-26 mutations in sporadic and inherited sensorineural deafness. Lancet 351, 394-398. doi: 10.1016/S0140-6736(97)11124-2

Feldmann, D., Le Marechal, C., Jonard, L., Thierry, P., Czajka, C., Couderc, R., et al. (2009). A new large deletion in the DFNB1 locus causes nonsyndromic hearing loss. Eur. J. Med. Genet. 52, 195-200. doi: 10.1016/j.ejmg.2008.11.006

Fu, X., An, Y., Wang, H., Li, P., Lin, J., Yuan, J., et al. (2021). Deficiency of $\mathrm{Klc} 2$ induces low-frequency sensorineural hearing loss in C57BL/6 J mice and human. Mol. Neurobiol. 58, 4376-4391. doi: 10.1007/s12035-021-02422-w

Guo, L., Cao, W., Niu, Y., He, S., Chai, R., and Yang, J. (2021). Autophagy regulates the survival of hair cells and spiral ganglion neurons in cases of noise, ototoxic drug and age-induced sensorineural hearing loss. Front. Cell. Neurosci. 15:760422. doi: 10.3389/fncel.2021.760422

He, Z., Guo, L., Shu, Y., Fang, Q., Zhou, H., Liu, Y., et al. (2017). Autophagy protects auditory hair cells against neomycin-induced damage. Autophagy 13, 1884-1904. doi: 10.1080/15548627.2017.1359449

Jagger, D. J., and Forge, A. (2015). Connexins and gap junctions in the inner ear-it's not just about $\mathrm{K}+$ recycling. Cell Tissue Res. 360, 633-644. doi: $10.1007 /$ s00441-014-2029-z 
Jiang, R., Taly, A., and Grutter, T. (2013). Moving through the gate in ATP-activated P2X receptors. Trends Biochem. Sci. 38, 20-29. doi: 10.1016/j. tibs.2012.10.006

Johnson, S.L., Ceriani, F., Houston, O., Polishchuk, R., Polishchuk, E., Crispino, G., et al. (2017). Connexin-mediated signaling in nonsensory cells is crucial for the development of sensory inner hair cells in the mouse cochlea. J. Neurosci. 37, 258-268. doi: 10.1523/jneurosci.2251-16.2016

Kelsell, D. P., Dunlop, J., Stevens, H. P., Lench, N. J., Liang, J., Parry, G., et al. (1997). Connexin 26 mutations in hereditary non-syndromic sensorineural deafness. Nature 387, 80-83. doi: 10.1038/387080a0

Kikuchi, T., Kimura, R.S., Paul, D.L., and Adams, J.C. (1995). Gap junctions in the rat cochlea: immunsohistochemical and ultrastructural analysis. Anat. Embryol. (Berl) 191, 101-118. doi: 10.1007/BF00186783

Koefoed-Johnsen, V., and Ussing, H. H. (1958). The nature of the frog skin potential. Acta Physiol. Scand. 42, 298-308. doi: 10.1111/j.1748-1716.1958. tb01563.x

Kraus, H. J., and Aulbach-Kraus, K. (1981). Morphological changes in the cochlea of the mouse after the onset of hearing. Hear. Res. 4, 89-102. doi: 10.1016/03785955(81)90038-1

Liang, C., Zhu, Y., Zong, L., Lu, G. J., and Zhao, H. B. (2012). Cell degeneration is not a primary causer for Connexin26 (GJB2) deficiency associated hearing loss. Neurosci. Lett. 528, 36-41. doi: 10.1016/j.neulet.2012.08.085

Liu, Y.-P., and Zhao, H.-B. (2008). Cellular characterization of Connexin26 and Connnexin30 expression in the cochlear lateral wall. Cell Tissue Res. 333, 395-403. doi: 10.1007/s00441-008-0641-5

Mammano, F. (2019). Inner ear connexin channels: roles in development and maintenance of cochlear function. Cold Spring Harb. Perspect. Med. 9:a033233. doi: 10.1101/cshperspect.a033233

Mammano, F., and Bortolozzi, M. (2018). $\mathrm{Ca}^{(2+)}$ signaling, apoptosis and autophagy in the developing cochlea: milestones to hearing acquisition. Cell Calcium 70, 117-126. doi: 10.1016/j.ceca.2017.05.006

Mazzarda, F., D’Elia, A., Massari, R., De Ninno, A., Bertani, F.R., and Businaro, L. (2020). Organ-on-chip model shows that ATP release through connexin hemichannels drives spontaneous $\mathrm{Ca}^{(2+)}$ signaling in non-sensory cells of the greater epithelial ridge in the developing cochlea. Lab Chip. 20, 3011-3023. doi: $10.10 .1039 / \mathrm{d} 0 \mathrm{lc} 00427 \mathrm{~h}$

Mei, L., Chen, J., Zong, L., Zhu, Y., Liang, C., Jones, R. O., et al. (2017). A deafness mechanism of digenic Cx26 (GJB2) and Cx30 (GJB6) mutations: reduction of endocochlear potential by impairment of heterogeneous gap junctional function in the cochlear lateral wall. Neurobiol. Dis. 108, 195-203. doi: 10.1016/j.nbd.2017.08.002

Mishra, S., Pandey, H., Srivastava, P., Mandal, K., and Phadke, S. R. (2018). Connexin 26 (GJB2) mutations associated with non-syndromic hearing loss (NSHL). Indian J. Pediatr. 85, 1061-1066. doi: 10.1007/s12098-018 $-2654-8$

Muto, S., Asano, Y., Wang, W., Seldin, D., and Giebisch, G. (2003). Activity of the basolateral $\mathrm{K}+$ channels is coupled to the Na+-K+-ATPase in the cortical collecting duct. Am. J. Physiol. Renal. Physiol. 285, F945-F954. doi: 10.1152/ajprenal.00081.2003

Nin, F., Hibino, H., Doi, K., Suzuki, T., Hisa, Y., and Kurachi, Y. (2008). The endocochlear potential depends on two $\mathrm{K}+$ diffusion potentials and an electrical barrier in the stria vascularis of the inner ear. Proc. Natl. Acad. Sci. U S A 105, 1751-1756. doi: 10.1073/pnas.0711463105

Pandya, A., Arnos, K. S., Xia, X. J., Welch, K. O., Blanton, S. H., Friedman, T. B., et al. (2003). Frequency and distribution of GJB2 (connexin 26) and GJB6 (connexin 30) mutations in a large North American repository of deaf probands. Genet. Med. 5, 295-303. doi: 10.1097/01.GIM.0000078026.01140.68

Pandya, A., O’Brien, A., Kovasala, M., Bademci, G., Tekin, M., and Arnos, K. S. (2020). Analyses of del(GJB6-D13S1830) and del(GJB6-D13S1834) deletions in a large cohort with hearing loss: caveats to interpretation of molecular test results in multiplex families. Mol. Genet. Genomic. Med. 8:e1171. doi: $10.1002 / \mathrm{mgg} 3.1171$

Qu, Y., Tang, W., Zhou, B., Ahmad, S., Chang, Q., Li, X., et al. (2012). Early developmental expression of connexin26 in the cochlea contributes to its dominate functional role in the cochlear gap junctions. Biochem. Biophys. Res. Commun. 417, 245-250. doi: 10.1016/j.bbrc.2011.11.093

Rodriguez-Paris, J., and Schrijver, I. (2009). The digenic hypothesis unraveled: the GJB6 del(GJB6-D13S1830) mutation causes allele-specific loss of
GJB2 expression in cis. Biochem. Biophys. Res. Commun. 389, 354-359. doi: 10.1016/j.bbrc.2009.08.152

Schmid, R., and Evans, R. J. (2019). ATP-gated P2X receptor channels: molecular insights into functional roles. Annu. Rev. Physiol. 81, 43-62. doi: 10.1146/annurev-physiol-020518-114259

Shahidullah, M., Mandal, A., Beimgraben, C., and Delamere, N. (2012). Hyposmotic stress causes ATP release and stimulates Na, K-ATPase activity in porcine lens. J. Cell. Physiol. 227, 1428-1437. doi: 10.1002/jcp.22858

Snoeckx, R. L., Huygen, P. L., Feldmann, D., Marlin, S., Denoyelle, F., Waligora, J., et al. (2005). GJB2 mutations and degree of hearing loss: a multicenter study. Am. J. Hum. Genet. 77, 945-957. doi: 10.1086/497996

Sueta, T., Paki, B., Everett, A., and Robertson, D. (2003). Purinergic receptors in auditory neurotransmission. Hear. Res. 183, 97-108. doi: 10.1016/s03785955(03)00221-1

Sun, Y., Tang, W., Chang, Q., Wang, Y., Kong, W., and Lin, X. (2009). Connexin 30 null and conditional connexin 26 null mice display distinct pattern and time course of cellular degeneration in the cochlea. J. Comp. Neurol. 516, 569-579. doi: 10.1002/cne.22117

Tayoun, A. N., Mason-Suares, H., Frisella, A. L., Bowser, M., Duffy, E., Mahanta, L., et al. (2016). Targeted droplet-digital PCR as a tool for novel deletion discovery at the DFNB1 locus. Hum. Mutat. 37, 119-126. doi: 10.1002/humu.22912

Telang, R. S., Paramananthasivam, V., Vlajkovic, S. M., Munoz, D. J., Housley, G. D., and Thorne, P. R. (2010). Reduced P2x 2 receptor-mediated regulation of endocochlear potential in the ageing mouse cochlea. Purinergic Signal. 6, 263-272. doi: 10.1007/s11302-010-9195-6

Teubner, B., Michel, V., Pesch, J., Lautermann, J., Cohen-Salmon, M., Sohl, G., et al. (2003). Connexin30 (Gjb6)-deficiency causes severe hearing impairment and lack of endocochlear potential. Hum. Mol. Genet. 12, 13-21. doi: 10.1093/hmg/ddg001

Tsuchiya, K., Wang, W., Giebisch, G., and Welling, P. (1992). ATP is a coupling modulator of parallel $\mathrm{Na}, \mathrm{K}$-ATPase-K-channel activity in the renal proximal tubule. Proc. Natl. Acad. Sci. US A 89, 6418-6422. doi: 10.1073/pnas.89.14.6418

Verselis, V. K. (2019). Connexin hemichannels and cochlear function. Neurosci. Lett. 695, 40-45. doi: 10.1016/j.neulet.2017.09.020

Wang, Y., Chang, Q., Tang, W., Sun, Y., Zhou, B., Li, H., et al. (2009). Targeted connexin26 ablation arrests postnatal development of the organ of corti. Biochem. Biophys. Res. Commun. 385, 33-37. doi: 10.1016/j.bbrc.2009. 05.023

Wangemann, P. (2002). K+ cycling and its regulation in the cochlea and the vestibular labyrinth. Audiol. Neurotol. 7, 199-205. doi: 10.1159/000063736

Wei, H., Chen, Z., Hu, Y., Cao, W., Ma, X., Zhang, C., et al. (2021). Topographically conductive butterfly wing substrates for directed spiral ganglion neuron growth. Small 17:e2102062. doi: 10.1002/smll.202102062

Wilch, E., Azaiez, H., Fisher, R. A., Elfenbein, J., Murgia, A., Birkenhager, R., et al. (2010). A novel DFNB1 deletion allele supports the existence of a distant cis-regulatory region that controls GJB2 and GJB6 expression. Clin. Genet. 78 267-274. doi: 10.1111/j.1399-0004.2010.01387.x

Wilch, E., Zhu, M., Burkhart, K. B., Regier, M., Elfenbein, J. L., Fisher, R. A., et al. (2006). Expression of GJB2 and GJB6 is reduced in a novel DFNB1 allele. Am. J. Hum. Gen. 79, 174-179. doi: 10.1086/505333

Yu, N., and Zhao, H. B. (2009). Modulation of outer hair cell electromotility by cochlear supporting cells and gap junctions. PLoS One 4:e7923. doi: 10.1371/journal.pone.0007923

Zhang, Y., Li, Y., Fu, X., Wang, P., Wang, Q., Meng, W., et al. (2021). The detrimental and beneficial functions of macrophages after cochlear injury. Front. Cell Dev. Biol. 9:631904. doi: 10.3389/fcell.2021.631904

Zhang, S., Qiang, R., Dong, Y., Zhang, Y., Chen, Y., Zhou, H., et al. (2020a). Hair cell regeneration from inner ear progenitors in the mammalian cochlea. Am. J. Stem Cells 9, 25-35.

Zhang, S., Zhang, Y., Dong, Y., Guo, L., Zhang, Z., Shao, B., et al. (2020b). Knockdown of foxg1 in supporting cells increases the trans-differentiation of supporting cells into hair cells in the neonatal mouse cochlea. Cell. Mol. Life Sci. 77, 1401-1419. doi: 10.1007/s00018-019-03291-2

Zhang, Y., Zhang, S., Zhang, Z., Dong, Y., Ma, X., Qiang, R., et al. (2020) Knockdown of Foxg1 in Sox9+ supporting cells increases the transdifferentiation of supporting cells into hair cells in the neonatal mouse utricle. Aging (Albany NY) 12, 19834-19851. doi: 10.18632/aging.104009 
Zhu, Y., Chen, J., Liang, C., Zong, L., Chen, J., Jones, R. O., et al. (2015). Connexin26 (GJB2) deficiency reduces active cochlear amplification leading to late-onset hearing loss. Neuroscience 284, 719-729. doi: 10.1016/j.neuroscience. 2014.10.061

Zhu, Y., Liang, C., Chen, J., Zong, L., Chen, G. D., and Zhao, H. B. (2013). Active cochlear amplification is dependent on supporting cell gap junctions. Nat. Commun. 4:1786. doi: 10.1038/ncomms2806

Zhu, Y., and Zhao, H.-B. (2010). ATP-mediated potassium recycling in the cochlear supporting cells. Purinergic Signal. 6, 221-229. doi: 10.1007/s11302010-9184-9

Conflict of Interest: The authors declare that the research was conducted in the absence of any commercial or financial relationships that could be construed as a potential conflict of interest.
Publisher's Note: All claims expressed in this article are solely those of the authors and do not necessarily represent those of their affiliated organizations, or those of the publisher, the editors and the reviewers. Any product that may be evaluated in this article, or claim that may be made by its manufacturer, is not guaranteed or endorsed by the publisher.

Copyright (C) 2022 Chen, Chen, He, Gong, Li, Zhang, Lv, Mammano, Hou and Yang. This is an open-access article distributed under the terms of the Creative Commons Attribution License (CC BY). The use, distribution or reproduction in other forums is permitted, provided the original author(s) and the copyright owner(s) are credited and that the original publication in this journal is cited, in accordance with accepted academic practice. No use, distribution or reproduction is permitted which does not comply with these terms. 